\title{
The Influence of Metaphor on Sense-impression in English
}

\author{
Shufang Cheng \\ Zhengzhou Institute of Aeronautical and Industrial Management, Zhengzhou, China \\ Email: sophiacsf@126.com
}

\begin{abstract}
This paper discusses metaphor as a figure of speech first, and then talks about metaphor and synaesthesia from a cognitive perspective. In order to explain the metaphorical use of sense-impression in English, it borrows examples from some literary works. Finally, it draws the conclusion that metaphor has exerted a great influence on sense-impression in English.
\end{abstract}

Index Terms - metaphor, synaesthetic metaphor, sense-impression

\section{INTRODUCTION}

Metaphor has traditionally been viewed as the most important form of figurative language use, and is usually seen as reaching its most sophisticated forms in literary or poetic languages. Metaphor is like a simile, also makes a comparison between two unlike elements, but unlike a simile, this comparison is implied rather than stated. A metaphor is a figure of literary speech where one object is literally referred to as another. For example, my cat is a ball of fire would be a metaphor because the cat is being referred to as a ball of fire. A metaphor is also when two unlike things are compared directly to show some common quality between the two things. An example of a metaphor is "Time is a thief". Time is not really a thief, but both can be fleeting.

According to The Oxford English Dictionary, metaphor is the figure of speech in which a name or descriptive term is transferred to some object different from, but analogous to, that to which it is properly applicable; an instance of this, a metaphorical expression. For example,

(1) Happiness is a butterfly, which, when pursued, is always just beyond your grasp, but which, if you will sit down quietly, may alight upon you.

(2) Books are my sweethearts in my youth, my bosom friends in my middle age, and my companions in my declining years.

(3) Faith is the bird that feels the light when the dawn is still dark.

In sentence (1), a kind of feeling is portrayed as an insect; in sentence(2) books are regarded as human beings; while in sentence(3) faith is said to be a bird.

From the examples above, we can find that metaphor is somewhat like simile in that it involves the identification of resemblances, but that metaphor goes further by causing a transference, where properties are transferred from one concept to another.

\section{TERMINOLOGY OF METAPHOR}

In a figure of speech an implied comparison is made between two unlike things that actually have something in common. A metaphor expresses the unfamiliar (the tenor) in terms of the familiar (the vehicle). When Neil Young sings, "Love is a rose," "rose" is the vehicle for "love," the tenor. (In cognitive linguistics, the terms target and source are roughly equivalent to tenor and vehicle.)

There are generally two concepts that are involved in a metaphor. One is the starting point or described concept ('happiness' in sentence(1)) that is often called the target domain; the other is the comparison concept or the analogy ('a butterfly' in the same sentence) that is often called the source domain. In I. A. Richard's (1936) terminology the former is called the tenor and the latter, the vehicle.

\section{TYPES OF METAPHOR}

Metaphors can be classified in a range of different ways, based on various criteria, from complexity to level of usage.

\section{A. Absolute Metaphor}

Absolute metaphor is one where there is absolutely no connection between the subject and the metaphor.For example,

(4) I am the dog end of every day.

(5) That is worth less than a dead digeridoo.

(6) We faced a scallywag of tasks. 
In a non-absolute metaphor, the basic idea and the metaphor have some resemblance, for example using 'box' as a metaphor for 'house' or 'tube' for 'train'. A value of an absolute metaphor is in the way that it can confuse and hence make people think hard about the meaning of something. We seek always to find some meaning and hence some learning may arise. Absolute metaphors are also useful when you are at a loss for words. They can thus communicate frustration, confusion and uncertainty. The absolute metaphor is also known as a paralogical metaphor or antimetaphor.

\section{B. Active Metaphor}

An active metaphor is one which is relatively new and hence is not necessarily apparent to all listeners, although if the metaphor is well-selected, it will be easy enough to understand. For example,

(7) Let me compare thee to an artic day, sharp and bright, forever light...

(8) It's been a purple dinosaur of a day.

(9) You're looking pretty rabbit -- what's up?

Active metaphors are often used in poetry and eloquent speech to stimulate the reader or listener. When words do not fit your known patterns of meaning, you are forced to think harder about them, their use and what is intended by the author. Their use is a sign of a fertile imagination, and this attribute of the originator may well be recognized by the audience. This makes active metaphors a particularly useful method of impressing other people. Done badly, however, active metaphors can be a sign of arrogance or someone who thinks they are more intelligent than perhaps they actually are. The active metaphor is also known as a live metaphor.

\section{Dead Metaphor}

A dead metaphor occurs where the once-evocative transferred image is no longer effective or even understood, perhaps being lost in the aeons of time.

(10) Fabulous was something worthy of fable. Like many other superlatives, it has lost its original edge and now just means 'good'.

(11) Money was so called because it was first minted at the temple Juno Moneta.

(12) The origin of 'the whole nine yards' seems unknown, even to an expert word website.

Dead metaphors are dead in the sense that they no longer act as metaphors -- they just become plain words, with a simple functional meaning. In a sense, this is how language develops. Somebody tries to explain something by making up a word that conjures up an image, and eventually the word becomes a standard in the language, with it's original image being lost or evolved. In the 'dumbing down' of language, the rich meaning of many words becomes lost, and thus many metaphors lose their meaning. To understand the metaphoric quality of many words requires that their origins are studied.

\section{Extended Metaphor}

An extended metaphor is one where there is a single main subject to which additional subjects and metaphors are applied. The extended metaphor may act as a central theme, for example where it is used as the primary vehicle of a poem and is used repeatedly and in different forms. For example,

(13) He is the pointing gun, we are the bullets of his desire.

(14) All the world's a stage and men and women merely players.

(15) Let me count my loves of thee, my rose garden, my heart, my fixed mark, my beginning and my end.

The power of an extended metaphor is in the hammer blows that it applies, demonstrating the passion and commitment of the author. An extended metaphor is sometimes called a 'conceit', for example where the metaphoric theme of a poem is called its conceit, perhaps signifying the arrogance of the poet in assuming command of the language to the point of redefinition of terms that may be beyond many readers.

\section{E. Mixed Metaphor}

A mixed metaphor is one where the metaphor is internally inconsistent, for example where multiple metaphors are used which do not align with one another. The metaphors used often have some connection, although this is often tenuous or inappropriate. For example,

(16) He's a loose cannon who always goes off the deep end.

(17) He often shot his mouth off in the dark.

(18) A rolling stone gathers no bird in the hand.

(19) It was playing with fire in the belly.

Mixed metaphors are typically a result of trying to be too elaborate in speech and perhaps careless in the selection of metaphor. The result can be quite comic. This gives opportunity to use humor for deliberate effect.

\section{THE INFLUENCE OF METAPHOR ON SENSE-IMPRESSION}

\section{A. Sweetser's Identification of a Linguistic Metaphor}

Cognitivists argue that because of their presence in speaker's minds, metaphors exert influence over a wide range of 
linguistic behaviors. Sweetser(1990), for example, identifies a cross-linguistic metaphor MIND-AS-BODY, as when in English we speak of grasping an idea or holding a thought. She identifies this metaphorical viewing of the mental in terms of the physical as an important influence in the historical development of polysemy and of cognate words in related languages. Thus in English, the verb see has two meanings: the basic physical one of 'perceiving with the eyes' and metaphorically extended one of 'understanding' as in 'I see what you mean'. Sweetser discusses how over time verbs of sense perception in Indo-European languages have shown a consistent and widespread tendency to shift from the physical to the mental domain. Her claim is that this basic underlying metaphor underlies the paths o semantic change in many languages so that words of seeing come to mean understanding, words of hearing to mean obeying, and words of tasting to mean choosing, deciding or expressing personal preferences.

Sweetser's point is that historical semantic change is not random but is influenced by such metaphors as MIND-AS-BODY. Thus metaphor, as one type of cognitive structuring, is seen to drive lexical change in a motivated way, and provides a key to understanding the creation of polysemy and the phenomenon of semantic shift.

\section{B. The Relationship between 'Synaesthesia' and 'Metaphor'}

Synaesthesia refers to the use of metaphors in which terms relating to one kind of sense-impression are used to describe sense-impression of other kinds; the production of synesthetic effect in writing or an instance of this. (The Oxford English Dictionary, 1986) For example, a loud shirt; quiet color; cold words; sweet smile; heavy silence; soft green, etc.

From a cognitive perspective, synaesthesia is also a phenomenon of metaphor. The target domain and the source domain belong to different sense impression. Generally, we have five sense-impressions: visual impression, auditory impression, gustatory impression, olfactory impression and tactile impression. In literary works, terms relating to one kind of sense-impression are often used to describe sense-impression of other kinds in order to achieve a significant effect. Metaphor has the capacity to 'introduce a sensory logic at the semantic level alluding to a more complex scenario of interrelated meanings and experiences of the world'. (Cacciari, 1998:128) One of the most common types of metaphoric transfer is synaesthesia, i.e., the transfer of information from one sensory modality to another. The five sense-impressions are closely related to each other and interwoven with each other.

\section{The Metaphorical Use of Sense-impression}

Synaesthesia signifies the experience of two or more kinds of sensation when only one sense is being stimulated. In literature the term is applied to descriptions of one kind of sensation in terms of another; color is attributed to sounds, odor to colors, sound to odors, and so on. We often speak of loud colors, bright sound, and sweet music. A complex literary example of synaesthesia (which is sometimes also 'sense transference' or 'sense analogy') is this passage from Shelley's 'The Sensitive Plant'(1820):

(20) And the hyacinth purple, and white, and blue

Which flung from its bells a sweet peal anew

Of music so delicate, soft, and intense

It was felt like an odor within the sense.

The varicolored, bell-shaped flowers of the hyacinth send out a peal of music which effects a sensation as though it were (what in fact it is) the scent of the flowers.

Keats, in the 'Ode to a Nightingale'(1819), calls for a draught of wine:

(21) Tasting of Flora and the country green,

Dance, and Provencal song, and sunburnt mirth;

That is, he calls for a drink tasting of sight, color, motion, sound, and heat.

Occasional uses of synaesthesia imagery have been made by poets ever since Homer, such imagery became much more frequent in the Romantic period, and was especially exploited by the French Symbolists of the middle and later nineteenth century. Apart from the examples above, there are still other examples indicating the metaphorical use of sense-impression.

\section{Visual-Auditor}

(22) You see the creature with her curbstone English. (B. Shaw, Pygmalion)

In this sentence, curbstone English can be seen, which is a vivid example of auditory sense felt by visual sense.

(23) April, April

Laugh thy golden laughter...(W. Watson, Song)

Here laughter is shaded with the golden color as if it can be seen.

(24) In the air, always, was a might smell of sound that is seemed could sway the earth. With courageous words of artillery and spiteful sentence of musketry mingled red cheers. (S. Crane, The Red-Badge of Courage)

The word 'cheers' is modified by a color term 'red', which is vivid description of the scenario of the war field.

(25) The dusk was repeating them in a persistent whisper all around us, in a whisper that seemed to smell me menacingly like the first whisper of a rising wind.

(J. Conrad, Heart of Darkness)

(26) Like unto cicadae that in a forest sit upon a tree and pour forth their lily-like voice. (Homer)

In this sentence, 'voice' seems to have certain shape, a shape of the beautiful flower lily. 


\section{Gustatory-Tactile}

(27) This mustard is hot enough to bite your tongue.

We all know that mustard is a condiment, and it cannot bite your tongue actually. Since it is very hot condiment, you will feel your tongue is bitten if you have too much of it.

(28) Yet I live here, I live here too. I sing

Expertly civil-tongued with civil neighbors

On the high wires of first wireless reports,

Sucking the fake taste, the stony flavors

Of those sanctioned, old, elaborate retorts

(Seamus Heaney, Whatever You Say Say Nothing)

Here, a flavor is a stony object, which is good example of tasting is touching.

(29) The following for the record, in the light

Of everything before and since:

One bright May morning, nineteen-seventy-nine,

Just off the red-eye special from New York,

I'm on the train for Belfast, Plain, simple

Exhilaration at being back: the sea

At Skerries, the nuptial hawthorn bloom,

The trip north taking sweet hold like a chain.

On every bodily sprocket.

(Seamus Heaney, The Flight Path IV)

Here holding is tasting, which denotes touching is tasting.

3. Gustatory- Auditory

(30) And the verse of sweet old song

It flutters and murmurs still...(H. W. Longfellow, My Lost Youth)

(31)And like music on the waters

Is thy sweet voice to me. (Lord Byron. There be none of beauty's daughters)

(32) The stewardness flung open the door, and someone opened the emergency door at the back, letting in the sweet noise of their continuing mortality the idle splash and smell of heavy rain. (J. Cheever, The Country Husband)

In the three sentences above, we have 'sweet old song', 'sweet voice', and 'sweet noise'. These expressions are all the synaesthetic effect of gustatory impression to auditory impression.

\section{Olfactory-Auditory}

(33) Soft music like a perfume, and sweet light

Golden with audible odors exquisite

Swathe me with cerements for eternity (A. Symons, The Opium Smoker)

Here the music seems to have the odors of perfume, which will impress the people how excellent the music is.

(34) His voice was a censer that scattered strange perfume. (O. Wilde. Salome)

In this sentence, 'voice' is said to be a censer, which also stresses how good the voice is.

(35) Lifted their noses as they smelt music. (W. Shakespeare. The Tempest Act III)

Music can often be listened to, but can we smell the music? Here the particular use indicates that people enjoy the music very much.

(36) A loud perfume, which at my entrance, cried ev'n at the father's nose. (John. Donne)

Another interesting use of perfume here is that perfume can cry at one's nose. In fact, it means the odor of the perfume is very strong.

\section{Olfactory-Gustatory}

(37) The warm bitter sweet smell of clean Negro welcomed us as we entered the churchyard.

The terms 'bitter' and 'sweet' are all gustatory terms. They are used here to describe the 'smell' which is a olfactory term.

\section{Olfactory-Tactile}

(38) Splendid cheese, ripe and mellow, and with a two hundred horse-power scent about them that might have been warranted to carry three miles and knock a man over at two hundred yards.

\section{Tactile-Auditory}

(39) Cool the sound of the brook...(Longfellow, The Golden Legend)

(40) Music, when soft voices die,

Vibrates in the memory (P. B. Shelley, Music, when soft voices die)

(41) Thinking of these years, the only real thing I recall is the soft hiss of bicycle tyres on the main street. (American Dream)

(42) Here will we sit and let the sounds of music creep in our ears; Soft stillness and the night become the touches of sweet harmony. (W. Shakespeare)

\section{Combination of two or more senses}


(43) Soft music like a perfume and sweet light

Golden with audible odors exquisite

Swathe me with cerements for eternity. (Arthur Symons: The Opium Smoker)

(44) It's my soul that calls upon my name

How silver sweet sound lovers' tongues by night

Like softest music to attending ears. (W. Shakespeare: Romeo and Juliet Act II)

Here, in the two examples above, two or more sense-impressions are activated metaphorically such as soft music (Auditory-Tactile); sweet light (Gustatory-Visual); audible odors (Olfactory-Auditory); silver sound (Auditory-Visual); sweet sound (Auditory-Gustatory).

\section{CONCLUSION}

According to Lakoff and Johnson (1980), "the essence of metaphor is understanding and experiencing one kind of thing in terms of another". However, "... metaphor is not just a matter of language, that is, of mere words. On the contrary, human thought processes are largely metaphorical" (emphasis in original). In other words, "Metaphors as linguistic expressions are possible precisely because there are metaphors in a person's conceptual system"."Metaphoric expressions of the unity of the senses evolved in part from fundamental synesthetic relationships but owe their creative impulse to the mind's ability to transcend these intrinsic correspondences and forge new multisensory meanings. Intrinsic, synesthetic relations express the correspondences that are, extrinsic relations assert the correspondences that can be." (Marks, 1978, pp. 103)

We can say, without need for apprehension, that synaesthetic metaphors are indeed metaphors. Moreover, they can work just like most other metaphors (however that actually is!). The problem is, how easily can we say that they are derived in the same manner? For if they are not derived like other metaphors but have a type or extension/variation of truth behind them, do they come to have meaning via the same semantic processes as other metaphors?

The meanings for synaesthetic metaphors are not simply there, hard-wired and innate, but are generated through semantic processes and fashioned by time and cultural elements, much like other metaphors. The trends and universals of synaesthetic metaphors are built and evolve in the same manner as for other metaphors, through linguistic and cultural processes; and these trends and universals can be investigated from a linguistic standpoint.

The next step in investigation is to look at synaesthetic metaphors in other languages and cultures: uniformity in patterns across languages might indicate a more biological basis, while divergence would indicate the degree to which low-level, random synaesthesia is mediated by culture.

\section{REFERENCES}

[1] Cacciari, Cristina. (1998). "Why Do We Speak Metaphorically? Reflections on the Functions of Metaphor in Discourse and Reasoning." In Katz, Albert N; Cacciari, Cristina; Gibbs, Raymond W. Jr; Turner, Mark. (1998). Figurative Language and Thought. New York \& Oxford: Oxford University Press. 119-157

[2] I. A. Richards. (1936). The Philosophy of Rhetoric. Oxford, Oxford University Press.

[3] Lakoff, G., \& Johnson, M. (1980). Metaphors we live by. Chicago and London: University of Chicago Press.

[4] Marks, L. E. (1978). The unity of the senses. New York and London: Academic Press.

[5] Saeed, J. I. (2000). Semantics. Beijing: Teaching and Researching Press.

[6] Searle, J. R. (1979). Metaphor. In Ortony, A., (Ed.), Metaphor and thought. Cambridge: Cambridge University Press. 92-123

[7] Sweetser, Eve. (1990). From etymology to pragmatics: Metaphorical and cultural aspects of semantic structure. Cambridge: Cambridge University Press.

Shufang Cheng was born in Shanxi province, China in 1976. She received her M.A. degree in linguistics from Shanghai International Studies University, China in 2008.

She is currently an instructor in the School of Foreign Languages, Zhengzhou Institute of Aeronautical and Industrial Management, Zhengzhou, China. Her research interests include contrastive linguistics, pragmatics and college English teaching. 